\title{
緑地分野での復旧・復興の歩み
}

\section{A Progress of Restoration and Reconstruction from Earthquake in Landscape Architecture}

中瀬 勲* 上甫木昭春 ${ }^{* *}$ 赤澤 宏樹***

Isao NAKASE akiharu KAMIHOGI Hiroki AKAZAWA

はじめに

阪神・淡路大震災以降，復旧・復興に向けて，緊急事態 に対応した様々な現状調査, 提言, 計画策定などが進んで きた。ここでは，まちづくり，公園づくり，緑地づくり， さらには緑の住民参加やボランティア活動などに焦点を当 てながら，「1．阪神・淡路震災復興計画までの経緯」「2． 緑地分野の調査, 研究などの变遷」「3，緑地分野に関わ る復興事業の事例」「4．ボランティア活動などの支援」 について，この 3 年間の市民，行政，研究者やコンサル夕 ンッなどの復旧・復興に向けての動向を明らかにすること を目的とした。ここで用いた資料は兵庫県立「人と自然の 博物館」で収集し得たものを用いているため，全ての資料 を網羅したものではないことをお断りしておきたい。

\section{1．阪神・淡路震災復興計画までの経緯}

被災地域住民の一日も早い生活の安定と被災地の速やか な復旧・復興をめざして, 阪神・淡路震災復興計画（ひょ うごフェニックス計画）は, 平成 7 年 7 月 31 日に策定さ れた。その策定プロセスをまとめると，図一 1 に示すよう な流れとなる。

まず，この復興計画の策定に先立ち，1995 年 2 月 5 日 に「都市再生戦略懇話会」（座長：新野幸次郎・神戸大学: 名誉教授）が設置され，各種の県民会議（ひょうご住宅復 興会議他）の意見を反映させながら，「阪神・淡路震災復 興戦略ビジョン」( 3 月 30 日)が提言された。この提言を もとに，兵庫県は「阪神・淡路震災復興計画－基本構想」 （4月28日）を策定，発表した。この基本構想に基づき， 住宅復興，産業復興，インフラの復旧などに関する「緊急 3 力年計画」が先行的に策定され, 後に復興計画に吸収さ れることになる。

さらに，「フェニックス県民フォーラム」をはじめとす る被災者からの提言, 造園学会などの学術闷体, 市民付体, 県民などからの提言をもとに，5月11日に発足した「阪 神・淡路震災復興計画策定調査委員会」（委員長：三木信
・・神戸商科大学学長）で具体的な復興事業が検討・立案 され，「阪神・淡路震災復興計画」（6月29日）としてま とめられている。

この提言を受け，兵庫県では総合計画「兵庫 2001 年計 画」の総合的な点検作業における検討内容を踏まえ，各被 災市町の復興計画との調整をはかりつつ， 7 月 31 日「阪 神・淡路震災復興計画（ひょうごフェニックス計画）」を 策定するに到っている。

一方，国の「服神・淡路復興委員会」（委員長：下河辺 淳・東京海上研究所理事長）は 2 月 15 日に設置され，内 閣総理大臣の諮問を受けて，国が講ずべき施策の基本方針 及び基本方針に基づき講ずべき諸施策について検討を行い, 様々な意見，提言を提出している。復興に必要な地方公共 団体の財政負担は膨大であること，また，大都市地下直下 型地震からの復興は，今後のモデルとして国内外から注目

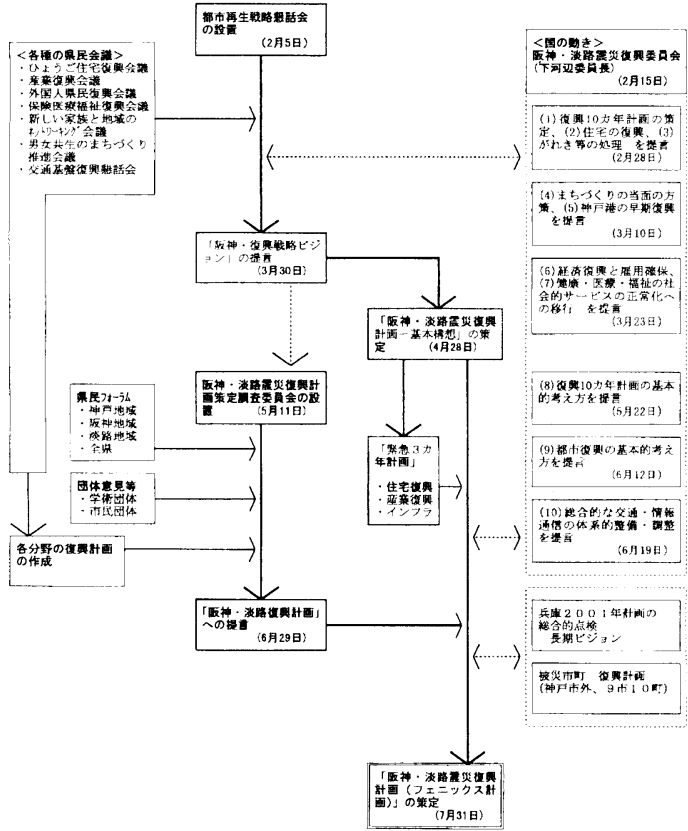

図－1 阪神・淡路震災復興計画（ひょうごフェニックス 計画) 策定までの経緯

*兵庫県立姫路工業大学自然 - 環境科学研究所 **大阪府立大学農学部 ${ }^{* * *}$ 兵庫県立人之自然の博物館 
されていることなどから，政府に対して復興計画の円滑な 推進をはかるための様々な支援が要請された。

以上のように，県民，諸団体，県行政，国などの相互協 力の成果として策定された「阪神・淡路復興計画」は，次 のような役割之性格を有している。

(1)震災復興のための, 兵庫県の行政計画である。

(2)被災者の自立復興を支援する計画である。

(3)市町の復興計画の指針となり，それを支援する計画 である。

(4)国・公団に対しては，必要な復興事業の推進や支援 を要請するものとなる。

（5）県民や各種団体，民間企業に対しては，生活・事業 再建や計画実現に向けた取り組みへの積極的な参画を 促す指針となる。

この復興計画の目標年次は, 震災による被害と影響の大 きさから，2005年（平成 17 年）で，その対象地域は，兵 庫県内の災害救助対象地域「10市 10 町」である。

復興計画の基本方針では，以下の 3 点が特筆されている。

(1)大震災発生から 6 ヶ月経過した現在もなお，緊急に 処理すべき課題への対応。（被災県民の生活を支援し ていくための応急対策，がれき処理対策，道路・港湾 等の復旧，社会福祉施設，文教施設等の復旧等）

(2)これまでの「利便」効摔」成長」を重視した都市づく りから，「安全」安心」「ゆとり」をキーワードとする都 市の復興。（従来の考えを超えた都市基盤の整備とそ れを活用したコミュニティ形成のモデル地域をめざす)

(3) 新たな視点から都市を再生する「創造的復興」の成就。

（阪神・淡路の文化的特性を活かし，新しい都市文明 の形成をめざす）

さらに，基本理念として，一人自然，人之人，人之社 会が調和する「共生社会」づくりーを掲げ，以下の事柄を推 進するものとしている。

(1)「兵庫 2001 年計画」の理念に基づく先導的な復興事業

（2）高齢化・成熟化の進む 21 世紀へ向けて，一人ひとり が主体的な自らの生活を創造しながら，共生する社会 ऽ゙くり

（3）この地域の文化的風土の上にたって，外に開かれた まちづくり

（4）自然への畏敬の念をもち, 自然と共生しながら, 命 を守り育む，アメニティ豊かな都市づくり

復興計画の基本方針，理念からは，これまでの都市づく りのあり方その屯のを問い直そうとする，並々なら決意 が感じられる。“創造的に復興”させることが，最も重要 なことであると，阪神・淡路震災復興計画策定調査委員会 資料にも述べられている。この「阪神・淡路震災復興計画」 には，今後の災害復興のモデルになることが求められてい るのである。

\section{2. 緑地分野の調査, 研究などの変遷}

震災後, 行政や学術村体をはじめとする様々な団体が, 緑地分野に関わる復興計画や提言, 調査報告などをまとめ, 刊行してきた。ここでは，これらの文献を整理することに より，震災関連の緑地分野に関わる調査活動の動きと行政 の復興への取り組みをまとめる。

文献の整理は，震災直後から現在までに兵庫県立人之自 然の博物館で収集した文献（調查報告書，行政刊行物，学 術書，一般雑誌など）を，(1)調查報告，(2)ハード整備に関 わる計画・提言，(3)ソフト整備に関わる計画・提言，(4)整 備マニュアルの 4 つに大別し, 時系列に沿って整理した。 以下，この 4 分類ごとに緑地分野に関わる復興の動向を述 べる。表一1に緑地分野に関わる復興の動向を示す。

（1）調査報告

[平成 7 年度]

被災直後から半年後までの避難・救援段階から復旧段階 において, 公園緑地の被害実態および避難地としての利用 実態や植物の被害軽減効果に関する報告が学術讨体を中心 に数多くみられる。日本造園学会阪神大震災調查特別委員 会は，公園抢よびその隣接部の被災状況や公園の避難地利 用の実態，および植物の被害と被害軽減効果を調查し，公 園の避難地としての施設性能と緑地の被害緩衝効果を検証

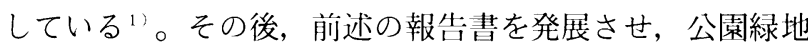
の配置計画，設計技術，管理運営上の課題をまとめてい $3^{2)}$ 。

表-1 緑地分野に関わる復興の動向

\begin{tabular}{|c|c|c|c|c|c|c|c|}
\hline & 調查·報告 & $\begin{array}{l}\text { 文 } \\
\text { t }\end{array}$ & $\begin{array}{l}\text { ハード整犕に } \\
\text { 関わる計画 }\end{array}$ & $\begin{array}{l}\text { ソフト整備に } \\
\text { 関わる計画 }\end{array}$ & $\begin{array}{l}\text { 女 } \\
\text { a }\end{array}$ & 整備マニュアル & $\begin{array}{l}\text { 文 } \\
\text { 施 }\end{array}$ \\
\hline $\begin{array}{l}\text { 平 } \\
\text { 成 } \\
7\end{array}$ & 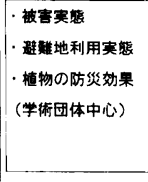 & $\begin{array}{l}2 \\
3 \\
4\end{array}$ & 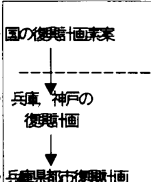 & 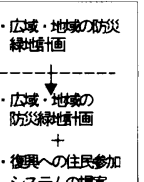 & $\begin{array}{l}15 \\
16 \\
19 \\
14 \\
13 \\
17 \\
18 \\
20\end{array}$ & & \\
\hline $\begin{array}{l}\text { 平 } \\
\text { 成 } \\
8 \\
8 \\
\text { 年 }\end{array}$ & 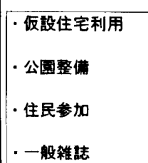 & $\begin{array}{l}5 \\
6 \\
7 \\
\end{array}$ & 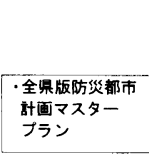 & & 21 & & \\
\hline $\begin{array}{l}\text { 平 } \\
\text { 成 }\end{array}$ & 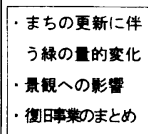 & $\mid \begin{array}{l}10 \\
11\end{array}$ & $\begin{array}{l}\text { 地方版防災都市 } \\
\text { t十画マススター } \\
\text { プラン }\end{array}$ & $\begin{array}{l}\text { ·地縞型コミュ } \\
\text { =ティの形成 }\end{array}$ & $\begin{array}{l}22 \\
23 \\
24\end{array}$ & \begin{tabular}{|l|}
-防多まちつくり \\
ガイドライン
\end{tabular} & 26 \\
\hline 年 & & & & & & 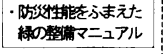 & 25 \\
\hline $\begin{array}{l}\text { 平 } \\
\text { 成 }\end{array}$ & - 防災公国の事例 & 12 & & & & 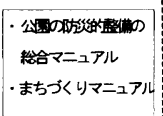 & $\begin{array}{ll}27 \\
28\end{array}$ \\
\hline 10 & & & & & & & \\
\hline
\end{tabular}


行政からは, 住宅・都市整備公団関西支社・日本造園学 会から公園の被害および避難利用の実態報告 ${ }^{3}$ が提出され た他に，阪神・淡路大震災兵庫県災害対策本部から，被災 直後の公園を拠点とした被災住民からの相談・要望への対 応, 医療相談・診療の実施, 緊急パトロールやボランティ ア活動の支援などの様々な救護・救援活動の様子が報告さ れている4)。

その他, 様々な団体が様々な地域で調査・報告を行って いるが，ここでは紙面の都合上省略した。

\section{[平成 8 年度]}

公園緑地に関する調査報告は，避難者すべてについて仮 設住宅などでの生活の場が確保され平成 7 年 9 月 30 日に すべての避難所が廃止されたことに伴い，ひょうご創生ま ちづくり研究センターの調査報告 ${ }^{3}$ に代表されるように, 避難地利用の実態把握から仮設住宅利用の実態把握へと移 行している。その後, 本格的な復旧の段階へ移行するにつ れて, 調査の内容も日本造園学会関東支部公共造園部会 ${ }^{6)}$ や住宅・都市整備公団・日本造園学会 ${ }^{7}$ など, 被害の実態 把握から公園整備に直接関わるものに移行している。

また, 震災淔後から被災・避難状況を報告してきた朝日 新聞社 ${ }^{8}$ などの一般書籍においても被災時のみどりの防災 機能が報告され，一般の人々の防災におけるみどりへの関 心の高さが何える。兵厙地域政策研究機構 公園緑地の復旧・復興と住民参加に関する調査も提出され, 行政主体ではなく住民主体による公園緑地の復旧・復興の 萌芽がみられる。

[平成 9 年度]

この時期になると，行政からも被災後 2 年間の県の復旧・ 復興事業をまとめたものが出版され国，震災後 3 年目に入 り復旧段階から復興段階へと移りつつあることがわかる。 この様にまちの復興が進む中で, 兵庫県・21世紀ひょう ご創造協会 11）などの, 宅地の更新に伴う緑の量的变化 や景観への影響の事例調査報告が見られる。これは, 無秩 序な宅地の更新による緑地の二次的被害の記録であると言 える。

[平成 10 年度]

震災後 3 年が経過し本格的な復興段階にはいると, 公園緑 地の機能などの調査報告はほとんど見られず, 都市緑化技 術開発機構 ${ }^{22}$ などの防災公園設㯰に直接参考になる被災地 以外の防災公園の事例などが報告される。

(2) ハード整備に関わる計画・提言

ハード整備に関わる計画・提言は, 震災のあった平成 7 年度に被災地域の復興計画が出揃い, その後, 非被災地域 の詳細な防災計画へと変化している。

[平成 7 年度]

震災当初は, 各種団体および学識経験者から, 広域緑地 計画中心の復興施策に関する提言が多数提出されてい

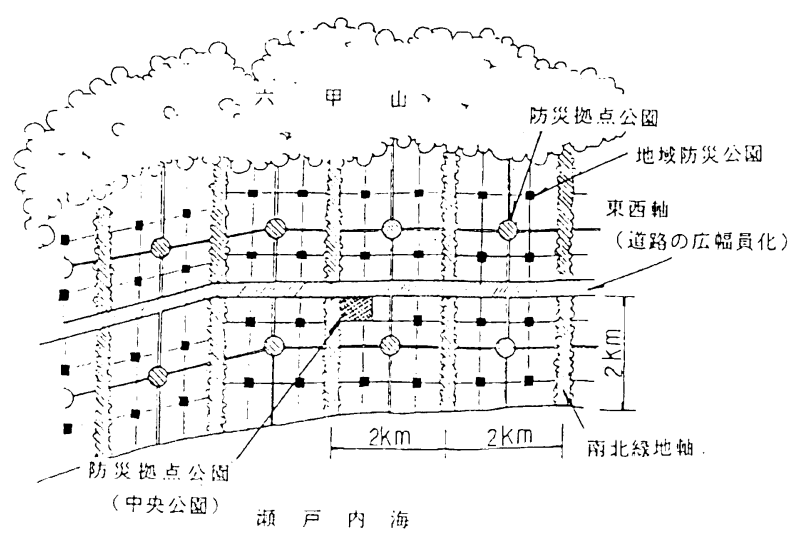

図ー2 国の示した緑地による防災機能の強化広域モデル

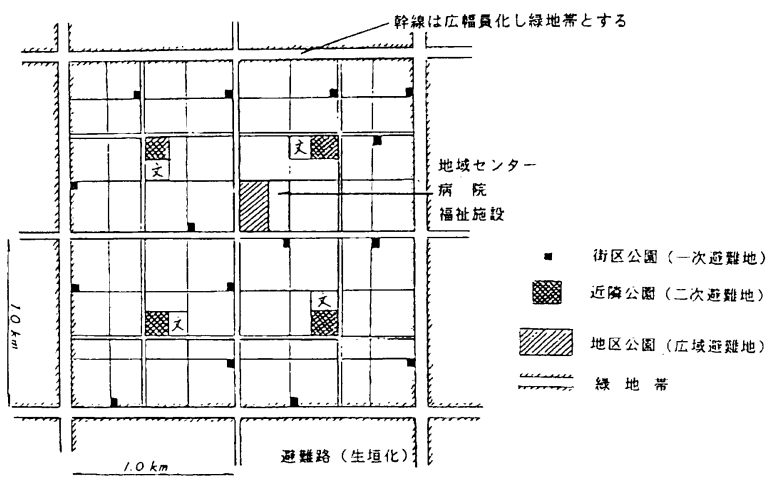

図ー3 国の示した緑地による防災機能の強化地区モデル

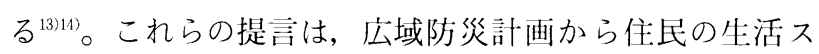
タイルに関するものまでを含み, 兵庫県, 神戸市の復興訃 画策定やその後のマスタープラン策定に対して, 様々なレ ベルで寄与したものと思われる。

行政が策定した計画を見ると, 阪神・淡路大震災のあっ た平成 7 年は, 早い段階で被災地の復興計画が策定されて 扝り, 早期復旧・復興に対する行政の対応の迅速さが伺え る。兵庫県の広域緑のマスタープラン策定調査報告書 ${ }^{15)}$ で は, 国の「公園緑地による防災機能の強化 (素案)」が報 告されている。これは行政が緑地からの都市基盤整備を提 案した初期のものであり, その後のハード整備に関わる復 興計画に大きな影響を与えることになる。この中で, 広域 レベルでは，六甲山と瀬戸内海といった自然に囲まれた都 市域を，河川による南北緑地軸と広幅員道路による東西緑 地軸を連携させることにより, 都市域全体の防災性能の向 上を図っている。地域レベルでは, 近隣住区每に近隣公園 と小学校を一体的に整備し，4近隣住区に 1 ケ所防災拠点 としての地区公園を設置する方向を示している。网一 2 に 国の示した緑地による防災機能の強化広域モデルを, 図一 3 に国の示した緑地による防災機能の強化地区モデルを示 す。この時点では, 緑地の具体的な防災性能や復旧後のコ ミュニティ形成をふまえた議論はされていない。また，こ の中の神户市の素案では, ハード整備の方針は国の素案を 踏襲しているが，近隣公園を公園における防災のソフト面 


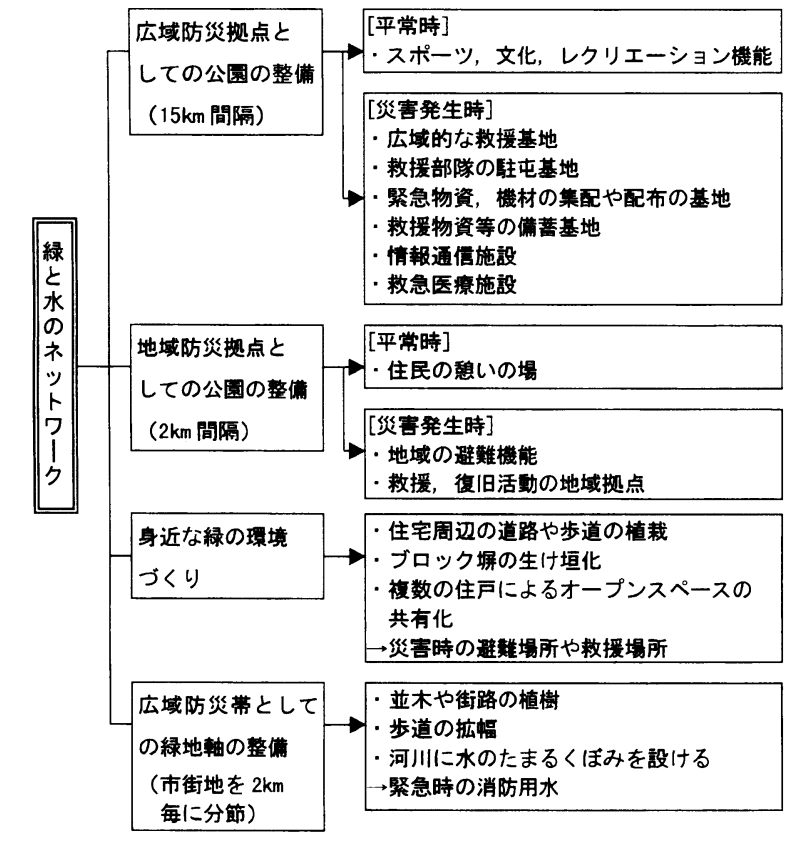

図－4 阪神・淡路震災復興計画における水とみどりのネッ トワークの整備方針

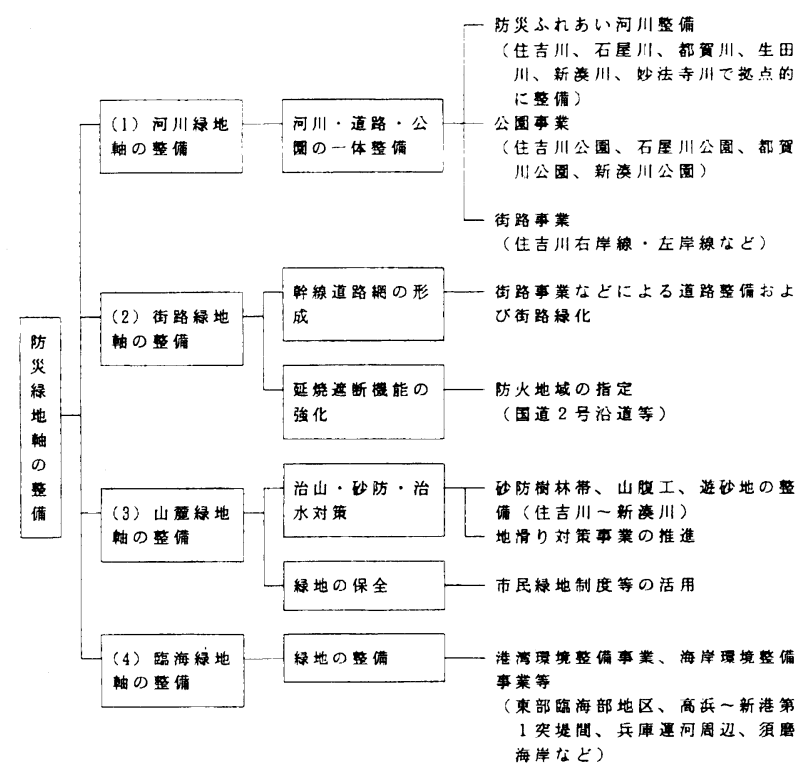

図ー 5 神戸市防災都市基盤施設の体系

（情報など）を支援するためのコミュニティ活動の場とし て一部位置づけている。

これをうけて，広域緑地計画を中心とした施策が被災直 後から動き出している。兵庫県は平成 7 年 2 月に「阪神・ 淡路震災復興計画 (素案)」を, 同 4 月に「阪神・淡路震 災復興計画一基本構想」(6) をま之め, 住宅復興, 産業復興, インフラの復旧等に関する「緊急 3 ヶ年計画」を先行させ た後, 平成 7 年 7 月 31 日に「阪神・淡路震災復興計画」 ${ }^{17}$ を策定した。図一 4 に阪神・淡路震災復興計画における水 とみどりのネットワークの整備方針を示す。この復興都市 計画が策定された後, 兵庫県都市住宅部は阪神・淡路震災

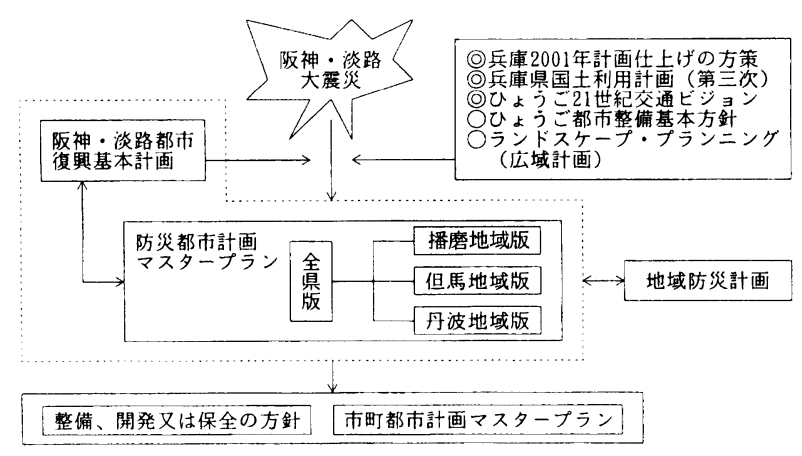

図ー6 兵庫県防災都市計画マスタープランの位置づけ

復興計画の中の都市づくりに関する分野を対象とした阪神・ 淡路震災都市復興計画 ${ }^{183}$ を策定しており, 県の法定都市計 画として定める「市街化区域および市街化調整区域の整備, 開発又は保全の方針」などの基本を示している。

神戸市は平成 7 年 3 月に「神戸市復興計画ガイドライン」199 をまとめており，その中で水とみどりを生かした安全性の 高い都市骨格の形成を目標としている。その後, 神戸市復 興計画審議会において審議を重ね, 平成 7 年 6 月 30 日に は「神戸市復興計画」20)を策定した。ここでは，公園緑地 を活用した防災緑地軸および防災拠点の整備による防災都 市基盤の形成を目標としている。図一 5 に神戸市防災都市 基盤施策の体系を示す。

[平成 8 年度 $]$

阪神・淡路大震災の翌年となる平成 8 年には, 都市防災 の課題が明らかになった被災地だけでなく, 間接的な被害 を受けた非被災地においても各都市機能をバランスよく配 置し安全性の向上を図るために，全県を対象とした防災都 市計画マスタープラン (全県版) ${ }^{21)}$ が策定されている。こ れは, 市町が定める市町都市計画マスタープランなど地域 レベルの防災計画の基本となるもので, 地域ごとの詳細な 防災まちづくりに向けた第一歩であるといえる。この後, 後述の防災都市計画マスタープラン（地域版）の策定とあ わせて, 兵庫県全域において安全・安心な都市づくりが議 論されることになる。図一6に兵庫県防災都市計画マスター プランの位置づけを示す。

[平成 9 年度]

前年に策定された防災都市計画マスタープラン（全県版） を受けて, 播磨, 但馬, 丹波の各地域ごとに防災都市計面 マスタープラン22223221)が策定された。この中では「地域固有 の防災資源」を整理しており, 全ての地域において自然之 共生した災害に強い環境づくりを第一の基本方針としてい る。

（3）ソフト整備に関わる計画・提言

[平成 7 年]

兵庫県が策定した阪神・淡路震災復興計画では, 計画推 進上の課題として「住民主体によるまちづくり」があげら 


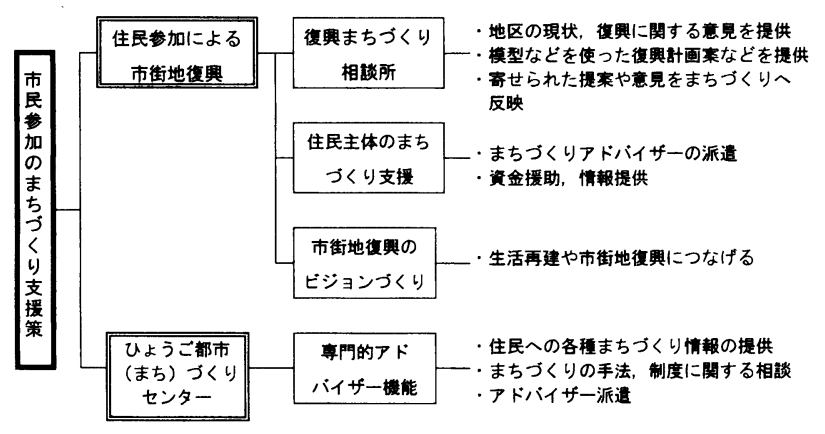

図ー7 阪神・淡路都市復興計画における市民参加のまち づくり支援策

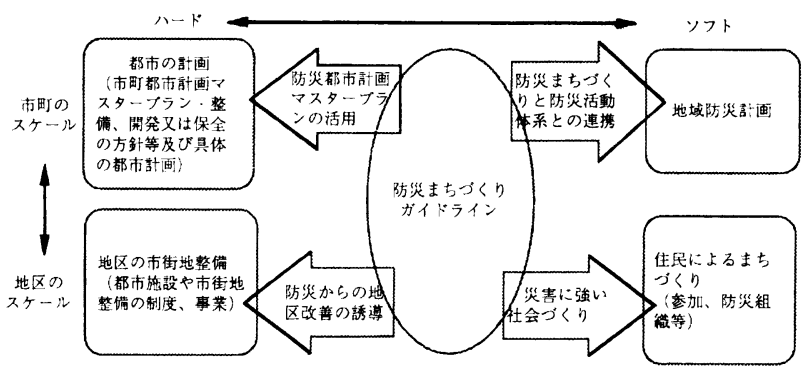

図－8＼cjkstart兵庫県防災まちづくりガイドラインの位置づけ

れ，被災地での自らの手でまちづくりを進めようとする気 運を支援していく方向性を出しているといえる。また，阪 神・淡路震災都市復興計画では, 都市復興を支援するシス テムの中で, 復興まちづくり相談所の設置, まちづくり組 織の結成支援と資金・情報提供，住民参加による方街地復 興のビジョンづくり，ひょうご都市づくりセンターの設置 などの「市民参加のまちづくり支援策」が掲げられ，地元 行政と住民とが協調して復興を進めていくためのより具体 的な方策がだされている。戍一7に阪神・淡路震災都市復 興計画における市民参加のまちづくり支援策を示す。 [平成 9 年]

防災都市計画マスタープラン（播磨地域版）において 「身近な地緣を維持・継我および広域的な縁の熟成を図り, 災害時の相互支援の素地を作る」ことが基本方針にあげら れており，コミュニティを育むことにより日常・緊急時の 生活を担保する傾向が非被災地においても必要なことを提 示している。

(4) 整備マニュアル

[平成 9 年]

震災後 3 年目の平成 9 年にはいると，これまでの緑の防 災性能に関する調查研究をふまえ, 防災植樹のすすめ ${ }^{25)}$ の 様な細かいレベルの緑の整備マニュアルが見られるように なる。ここでは，防火樹林の機能を生かす配列パターン， 管理方法や樹種リストまで網羅されている。

また，行政からは，兵庫県が防災まちづくりガイドライ ン ${ }^{26)}$ をとりまとめている。平成 8 年度までに策定された都 市復興計画および防災都市計画マスタープラン（全県版）
が広域的な防災計画であるのに対し，この防災まちづくり ガイドラインは地区レベルでの防災まちづくりの推進方法 をまとめたあのである。地区レべルのまちづくりは市街地 特性により様々な方法があるため, ガイドラインは基本的 な事項を整理するにとどまっているが，その位置づけは住 民の生活に最む近い地区レベルにおいてハード整備とソフ 卜整備を連携させるものである。図一 8 に兵庫県防災まち づくりガイドラインの位置づけを示す。このガイドライン は, 自然, 公園緑地などの防災資源の把握から住民主体に よるまちづくりの推進手法まで, 地区レベルのまちづくり に合致したきめ細やかなあのとなっている。

[平成 10 年]

本格的な復興段階にはいると, これまでの調査研究の成 果をまとめ, 公園緑地においても防災技術の総合的なマニュ アル27)が見られるようになる。

神戸市からは「安全で安心な住まいとまちづくりのガイ ドブック」先がまとめられている。ここでも防災まちづく りの手だてとしてみどりが位置づけられており, 各種助成 の紹介など具体的な緑化支援策もまとめられている。

(5) まとめ

行政の策定してきた復興関連の計画は, 被災直後は広域 レベルのハード整備中心であったが, 避難救援段階, 復旧 段階から復興段階になるにつれ地域・地区レベルの計画に 移行してきた状況がみられる。その後, 計画レベルが住民 の生活と密着したものになるにつれて, ソフト整備に関わ る項目が増加し，より具体的な防災計画になるにつれてガ イドラインなどの整備マニュアルが充実してきている。も ちろん, これらの動向に被災直後から行われてきた調查研 究活動の結果が大きく寄与していることは言うまでもない。 また，被災地の復興計画から非被災地のマスタープランに まで，住民主体のまちづくりやコミュニティの支援策が提 案されていることは, 非常に高く評価できる。今後は, 本 格的な住宅供給に伴い，新たなまちでのみどりづくりやそ れを通したコミュニティづくりなどが期待される。

\section{3．緑地分野に関わる復興事業の事例}

避難・救援, 復旧, 復興の段階每に緑地計画の新たな課 題が生じ，それぞれに対応すべく各種事業が進められてい るが, 前でまとめた復興計画の流れに伴い, 各種事業も広 域計画の拠点となる公園整備, 防災まちづくりから住民参 加型の緑づくり，コミュニティづくりへと変化している。

ここでは, 震災後の復旧・復興の流れに沿って, 緑地分 野に関わる代表的な復興事業の事例を紹介する。

（1）広域防災拠点としての公園整備

一三木総合防災公園一

三木震災記念公園は，震災以前は県の「ひょうご情報通 信回廊構想」の中核都市に位置づけられた「新都市ゾーン 
開発構想」にもとづき, 職・住・遊一体型のまちづくりが 検討されていたが, 震災後, 都市復興基本計画において全 県をカバーする広域防災拠点としての整備が位置づけられ た。その施設構成は, 災害時における応急活動の中心基地 および情報システムのバックアップなど災害対策における 保管機能を担う総合防災センターゾーンと, 関連施設ゾー ン, 総合防災公園ゾーンからなる。図一 9 に三木震災記念 公園の施設構成を示す。

三木総合防災公園は, 隣接する県立防災センターや消防 学校と一体となって, 災害時における駐屯・救助資機材な どの備蓄機能を有する総合防災公園ゾーンとして整備され る。

その計画方針は以下の 3 点である。

(1) 三木市における地域防災拠点として広域避難地の役割 を果たす

(2) 東播磨地域および三木市域の良好な都市環境の保全や 景観形成のため, 地域の豊かな自然や公園・緑地之有機的 に連携して緑のネットワークを形成する緑地保全機能を果 たす。

(3) 平時において全県的な総合公園として，スポーツ・レ クリエーション需要にも対応する施設整備を行う。

特に災害時の活用としては, 自衛隊などの駐屯地, 救助・ 復旧車雨などの駐車場, 救援物資の集積・分配場, ヘリポー ト, その他負傷者の一時収容, 一時避難地などが計画され ている。

このように, 前にまとめた被災直後に提出された避難・ 救援実態調査や広域緑地計画をふまえた上で，日常時には 総合運動公園として機能するよう計画されている。

（2）地域防災拠点としての公園整備 一津門中央公園一

兵庫県西宮市は, 市の東西には武庫川・成川の河川緑地 軸が存在するものの中央部には緑地が存在しないため, 公 園緑地を中心とする防災緑地軸の形成を進めている。この 中の浜手の地域防災拠点として, 津門中央公園の整備を進 めている。図一10に津門中央公園基本計画図（案）を示 す。

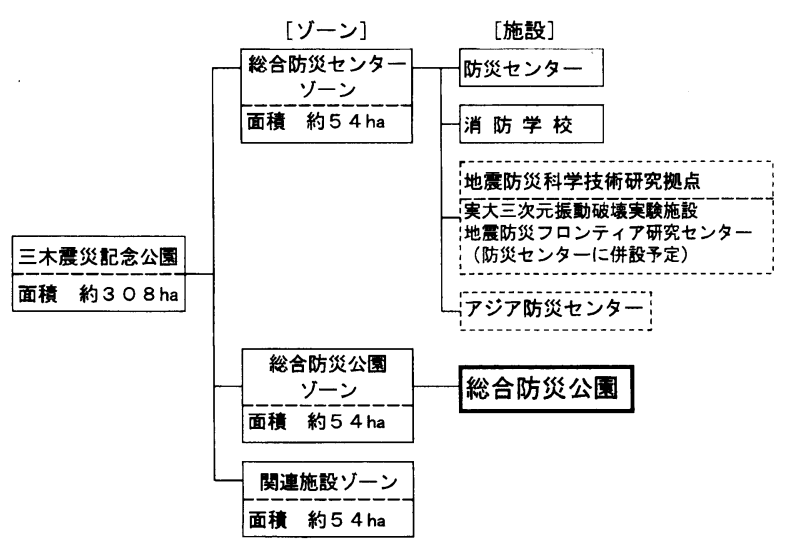

図-9 三木震災記念公園の施設構成
中央部の西宮中央運動公園がへリポート設置による救護 および応急要因の集積拠点に位置づけられているのに対し, 津門中央公園は国土 43 号線沿いに位置することや海側に 計画されている西宮沖地区広域防災拠点からも近いことか ら, 広域からの非常用物資の集配や救護の拠点に位置づけ られている。そのため, 災害対策本部のバックアップ機能 としての情報通信機器や, 食料, 飲料水, 資機材の備蓄・ 集配施設の整備が計画されている。また, 備蓄・集配施設 として大型シェルター, 耐震性眝水槽 $(200 \mathrm{t})$ などが整 備されるとともに，災害時にも配慮したトイレ・資材倉庫， 手押し付きポンプ付き井戸，炊き出しのできる釜戸，洗い 場にも利用できる壁線, ソーラーシステム活用の照明・ス プリンクラー，テントサイト植栽などが計画されており， 災害時の避難・救援活動を担保している。

以上の全ての施設がスポーツ・レクリエーション空間と しても活用されるよう工夫されており，日常時の住民との 高密度な接触を図ることによって災害時の避難地としての イメージを植え付けていく方策がとられている。

（3）防災から新しい都市づくりへ 一神戸東部新都心一

「阪神・淡路震災復興計画」「神戸市復興計画」のシン ボルプロジェクトとして, 神戸東部新都心の整備が進めら れている。山側の王子公園からつながる灘文化軸を構成す るプロジェクトでもあり, 業務・研究機能, 国際研究機能, 文化・交流機能, 居住機能を兼水備えた新しい都市づくり が試みられている。

臨海部には,「健康・環境・安全・福祉・文化」を基調 とする施設群が計画されており，これを囲む形で文化施設， 公的・民間住宅が配置される。図一11に神戸東部新都心 の主要な施設計画を示す。また, 表一 2 に神戸東部新都心 の主要な施設を示す。また,これらの施設以外にも, 新産 業の創造を誘導すべくライフインダストリーの展開が計画 されている。

これからの環境整備には, 環境単体ではなく経済や福祉 との融合による総合的な方向性が求められるが, 神戸東部 新都心の計画はこの新しい方向性を打ち出す可能性を持っ

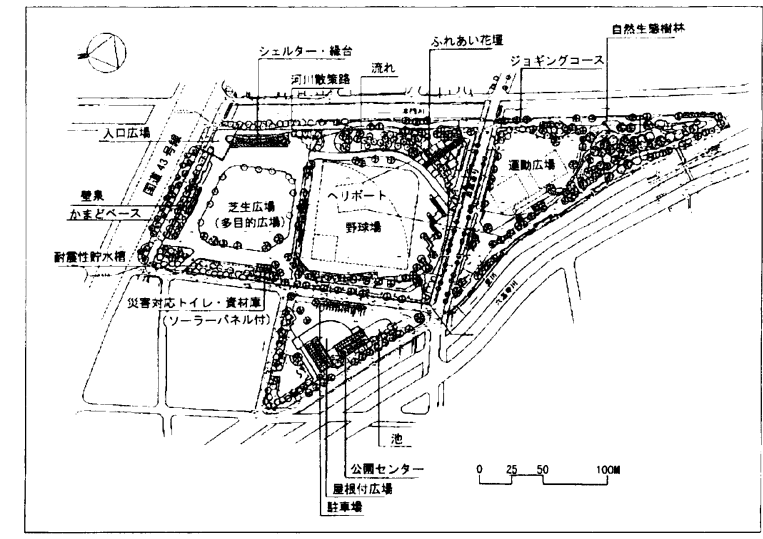

図－10 津門中央公園基本計画図（案） 


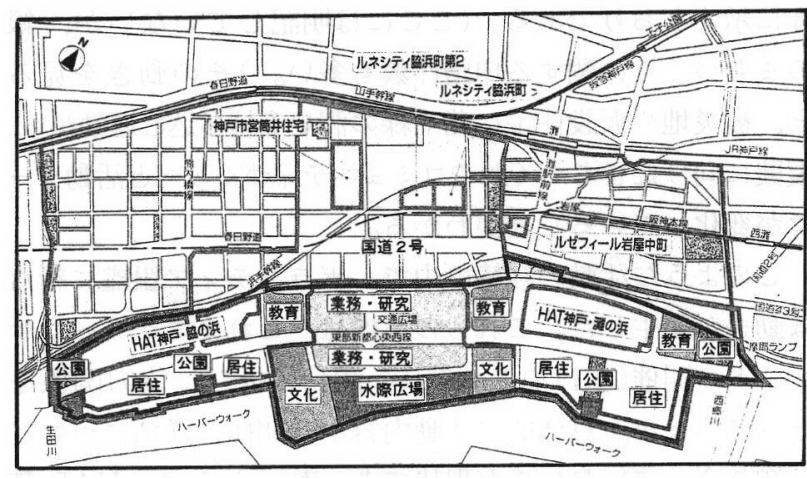

図ー11 神戸東部新都心の主要な施設計画

表 -2 神戸東部新都心の主要な施設

\begin{tabular}{|c|c|}
\hline 健康 & $\begin{array}{l}\cdot \text { WHO神戸センター } \\
\text { （世界保健機関健康開発総合研究センター） } \\
\text { ・ヘルスケアパーク } \\
\text { ・総合病院 }\end{array}$ \\
\hline 環境 & $\begin{array}{l}\cdot \text { 水際広場 } \\
\cdot \text { 国際エックスセンター } \\
\text { ・都市環境管理技術研究所構想 }\end{array}$ \\
\hline 安全 & $\begin{array}{l}\text { - 神戸防災地方合同庁舎 } \\
\text { ·水際広場 } \\
\text { ·神戸大学都市安全研究センター } \\
\text { ・災害医療センター }\end{array}$ \\
\hline 文化 & 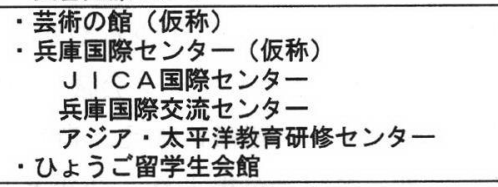 \\
\hline 福祉 & $\begin{array}{l}\text { ·兵庫長寿社会研究機構 } \\
\cdot \text { ボランティア活動支援センター（仮称） } \\
\text { ・ひようここ健康福祉総合センター }\end{array}$ \\
\hline
\end{tabular}

ている。計画されている施設が, 単なる施設群に終わるの ではなく,「健康・環境・安全・福祉・文化」が融合する 新しい都市のあり方を提案・実践していく要素としてネッ トワークしつつ機能することが期待される。

（4）住民主体の身近なみどりづくり

一深江駅前花苑整備一

阪神グリーンネット（代表 : 近藤公夫氏（神戸芸術工科 大学)）は, 震災後ばらばらに活動していたランドスケー プ関連の支援空口をネットワークとして一本化したあので, みどり関連の復興を担う提案から実践型の組織である。代 表的な活動としては, 神戸市東灘区の「深江地区まちづく

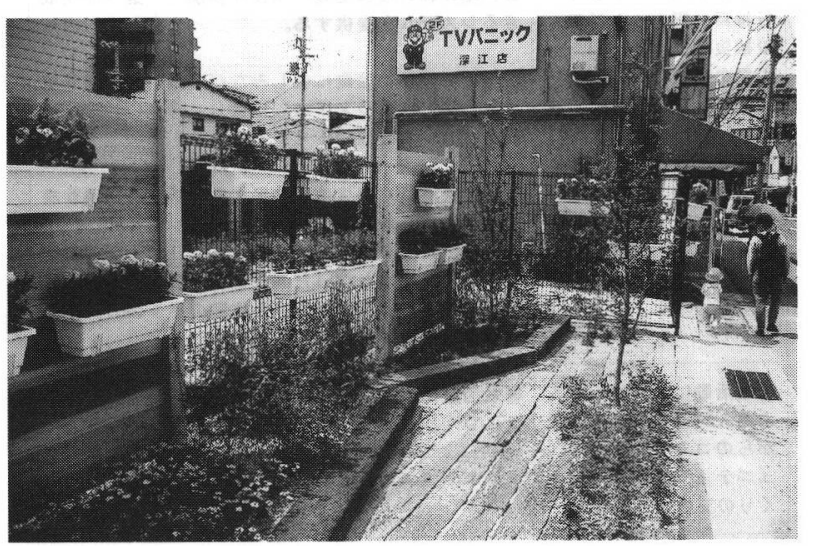

写真 -1 深江駅前花苑
り協議会」と民間コンサルタントとの共働による, 都市緑 化アクションプログラムの一つである深江駅前花苑がある。 写真一 1 に深江駅前花苑を示す。これは, 深江地区が白地 地区でありまちづくりが困難であるなかで, 緑からのまち づくりおよびコミュニティ形成を目的としたあのである。

深江駅前花苑は，まちづくり協議会が神戸市に深江駅前 空地の活用を提案し, 阪神グリーンネットと神戸市都市整 備公社が運営する「こうべまちづくりセンター」から派遣 された民間コンサルタントとともに整備を進めた。これは, 「兵庫 2001 年計画仕上げの方策」のさわやかな県土づくり における，住民主体のまちづくりの総合的支援による整備 として位置づけられる。また, 深江駅前花苑以外にも, ま ちづくり協議会は地区独自の「緑化まちづくり基本計画」 を策定しており, 中・長期的な地区の緑化計画をたててい る。

このように, 深江地区では住民と行政, 専門家グループ, 民間コンサルタントが柔軟に協力しあい, 後のまちづくり につながる緑化活動が行われている。また，阪神グリーン ネットには兵庫県や神戸市の職員が個人的に参加しており, 行政の支援システムや整備に対する専門的な知識を提供し ている。このような行政の枠組みの外での活動の支援は, 深江の緑化活動に非常に有効に機能した。今後の住民主体 のまちづくり・みよ゙りづくりに際しては, 住民, 行政から 専門家までの共働に加え, 行政が資金援助だけでなく制度 や手法などの専門家として参加することも望まれる。

\section{（5）みよ゙りが㕕むコミュニティ}

一南芦屋浜団地のだんだん畑一

芦屋浜沖の埋め立て地に整備された南芦屋浜団地では, 緑化活動を媒介にしたコミュニティづくりが試みられてい る。

まず入居前から，ご近所になる方々の顔を覚えあい入居 後のだんだん畑での野外活動を楽しんであらうために, 園 芸活動などを中心としたワークショップ「楽農講座」を開 催してきた。高齿者の方々が体調の都合で「楽農講座」に 参加できないとなれば，仮設住宅をまわっての「'出前'楽 農講座」もおこなっている。図一 12 に入居までの楽農講 座の内容を示す。

入居後は, 楽農講座に参加した住民を中心に「楽農準備 会」が結成され，自治会発足までにだんだん畑での緑化活 動を定着させようと，自主的に活動を行ってきた。ここで は, 参加メンバーの仮設住宅での体験, 楽農講座での設計 者からのアナウンスや入居後の楽農活動を通しての経験か ら, 参加者全員が「植物を育てること」よりも「それを通 してみんなが仲良くなること」を目標として活動している。 しかも，この「みんな」が，参加者全員ではなく団地の住 民全員を指していることは, 南芦屋浜団地が今後建設され る復興団地でのコミュニティづくりの参考になる最も大き 


\section{な点である。}

現在（平成 10 年 10 月時点）は, 春に植えたサッマイモ が収穫できるほどになり，これを用いた団地の住民同土が 知り合うきっかけとなるイベントを思案中である。しかし， 少数の参加メンバーにより814 戸もの世帯に活動を広報す ることは非常に困難であり，この広報上の問題から参加メ ンバーと非参加住民との間で䛊解が生じてきたことも事実 である。今後, 南芦屋浜讨地での活動を見本に復興闷地で のコミュニティが活性化されるためにも，行政が入居後の 活動に対してより積極的に支援していくことが期待される。

\section{4. ボランティア活動などの支援}

住民主体の「復興まちづくり」を進めるためには，行政や 企業から独立した相当規模の資金的支援が必要である。そ の実現に向けて，阪神・淡路ルネッサンス・ファンド $(\mathrm{H}$ $\mathrm{AR}$ 基金)が 1995 年 9 月に設立され，同年 11 月より「復 興まちづくり」の支援が開始された。「まち」と「すまい」の 再建だけでなく，「くらし」の再建を意図した基金である。

このファンドは, 被災地域のうち，原則として都市計画 決定された地区以外の広大な区域を対象に，復興まちづく りに取り組む様々な地元組織の活動と，それに協力するさ まざまな専門家を支援するもので，民間の非営利団体によ り運営されている。1997 年 12 月に決定された第 5 回まで の助成状況の中で, 緑のまちづくりに関する助成は, 表一

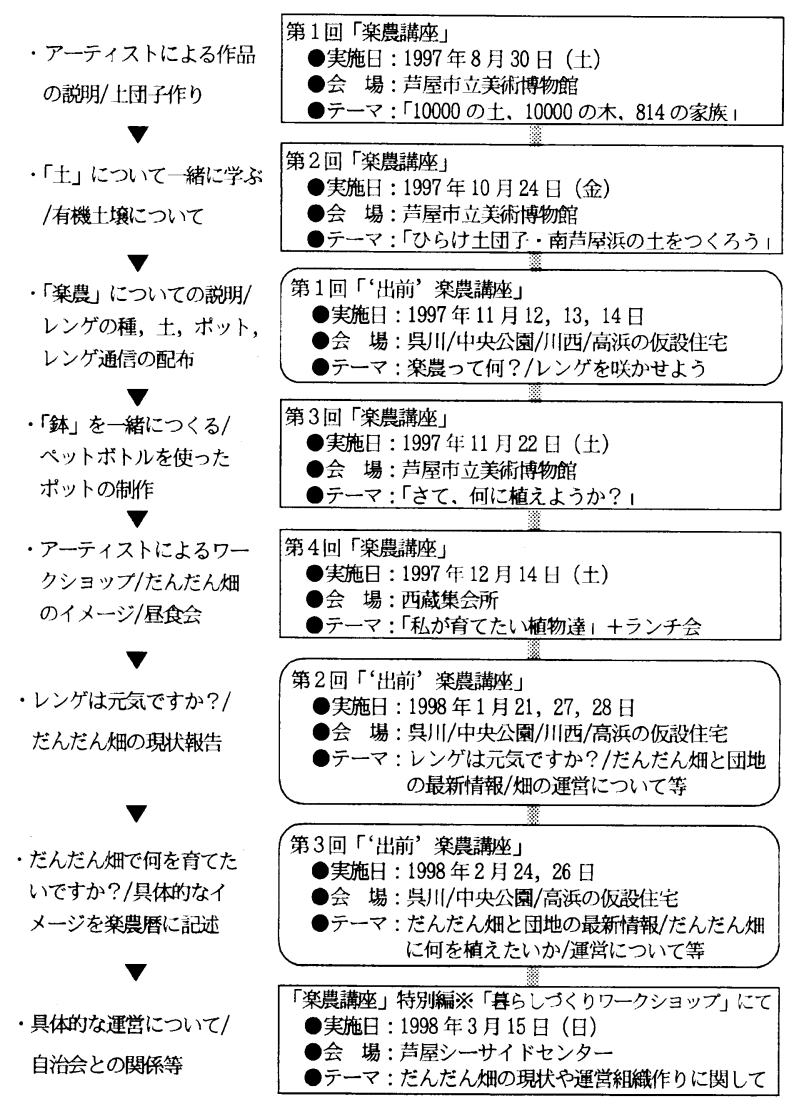

図-12 入居までの楽農講座の内容
3 に示すとおりである。（ここには明記していないが, 緑 のまちづくりに関する申請件数む多い。)その動きを見る と, 被災地や仮設住宅に花や緑の潤いを持ち込む運動から, 復興に向けたまちづくりやコミュニティづくりへと活動テー マが変化していることがわかる。

このような活動の経緯の中で，ボランティア組織に新た な動きが発生した。これらの組織は，これまでグリーンサ

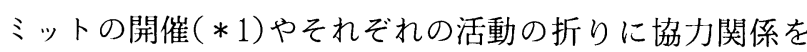
とっていたが，具体的な活動内容や各団体の詳細について は知り合っていないのが現状であった。さらに，HAR 基 金の助成を受けていない組織の中にも，活発な緑のまちつ くり支援活動を展開している団体がある(芦屋市民街づく り連絡会の「空き地を緑にーグリーンマントの会」, 西宮市 安井地区のケナフを植え，環境保全と人々の心にも楽しみ の場をつくる「申山ケナフの会」など)。そこで，阪神・大 震災から 4 年目の今年 2 月, 緑のまちづくり支援ネットワー ク形成の呼びかけがボランティア組織「阪神グリーンネッ ト」などにより行われ，4月第 1 回目の会合がもたれ，お 互いの情報の交換や発信を行うゆるやかなネットワーク 「緑のまちづくり支援ネットワーク会議」が発足した。さら に, 上記のボランティア組織に加え, 自然, 環境をテーマ にするボランティア組織が集まり，今年 8 月に「第 9 回全

\section{表一 3 HAR 基金の緑のまちづくりに関する助成}

\begin{tabular}{|c|c|c|c|}
\hline 活動のテ்-マ & $\begin{array}{l}\text { 活動の } \\
\text { グループ }\end{array}$ & 活動の内容 & 助成時期 \\
\hline $\begin{array}{l}\text { ガしキに花 } \\
\text { を咲かせま } \\
\text { しょう }\end{array}$ & $\begin{array}{l}\text { 服神大震災 } \\
\text { 隻興市民ま } \\
\text { ちつくり支 } \\
\text { 援ネットワ } \\
\text { ーク }\end{array}$ & 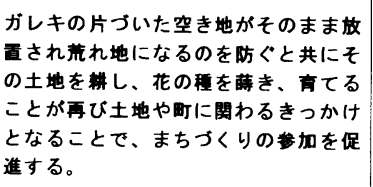 & $\begin{array}{l}\text { 第 } 1 \text { 回助成 } \\
\text { (50万円) }\end{array}$ \\
\hline 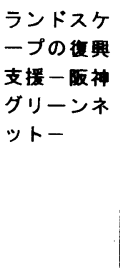 & $\begin{array}{l}\text { ランドスケ } \\
\text { 一プ推興支 } \\
\text { 晨会新 }\end{array}$ & 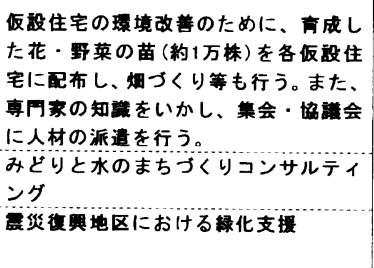 & $\begin{array}{l}\text { 第 } 4 \text { 回助成 } \\
(68 \text { 万円) } \\
\text { 第 } 5 \text { 回助成 } \\
(22 \text { 万円) }\end{array}$ \\
\hline $\begin{array}{l}\text { ドングリ撮 } \\
\text { 行神戸ー震 } \\
\text { 災被災地で } \\
\text { の緑の復興 } \\
\text { 活跏 }\end{array}$ & $\begin{array}{l}\text { ドングリネ } \\
\text { ット神戸 }\end{array}$ & 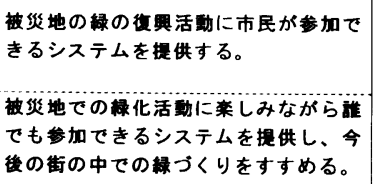 & $\begin{array}{l}\text { 第 } 3 \text { 回助成 } \\
\text { (124万円) } \\
\text { 第 } 4 \text { 回助成 } \\
\text { (74万円) }\end{array}$ \\
\hline $\begin{array}{l}\text { 地域住民の } \\
\text { ネットワー } \\
\text { クで行う自 } \\
\text { 主绿化活勤 }\end{array}$ & $\begin{array}{l}\text { 緣花コミュ } \\
\text { ニティ } \\
\text { 「四季」 }\end{array}$ & 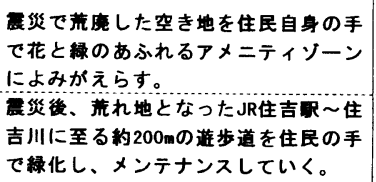 & $\begin{array}{l}\text { 第 } 3 \text { 回助成 } \\
\text { (50万円) } \\
\text { 第 } 4 \text { 回助成 } \\
\text { (45万円) }\end{array}$ \\
\hline $\begin{array}{l}\text { 植载活䡃に } \\
\text { よる入居前 } \\
\text { からのコミ } \\
\text { ュニティつ } \\
\text { くりの支援 }\end{array}$ & $\begin{array}{l}\text { 声屋だんだ } \\
\text { ん㚼・楽震 } \\
\text { 俱楽部 }\end{array}$ & $\begin{array}{l}\text { 植裁活娌による入居首からのコミュ } \\
\text { ティづくり支援 }\end{array}$ & $\begin{array}{l}\text { 第 } 5 \text { 回助成 } \\
\text { (50万स) }\end{array}$ \\
\hline
\end{tabular}

（注）HAR基金助成対象一筧衰より抜耕整理 
国トンボ市民サミット神戸大会」( *2) が阪神大震災の被災 地で開催された。その成果の一つは，「人と自然が共生す るネットワーク」結成の呼びかけが，神戸宣言に高らかに 盛り込まれたことである。これからのまちづくりでは，住 民，企業，行政のパートナーシップが求められるが，その 基礎となる人的ネットワークの必要性が合意され，その実 現に向けて歩みだしたことは極めて意義深いといえる。

このように，被災地では「復興まちづくり」に関わるボラ ンティア組織が，HAR 基金などの助成を受けながら着実 な成長を遂げつつあり，今後ともボランティ組織に対する 金，人，もの等の支援をさらに継続，強化していくことが 望まれる。

また，兵庫県は，生活県民ネット事務局を阪神・淡路大 震災復興支援館(フェニックスプラザ)に開設し，被災者の 生活再建に向けた活動に対する資金助成制度として「フェ ニックス活動助成事業」を平成 8 年度から実施している。 具体的には，1付体あたり 30 万円を限度に助成する一般 活動助成と，複数団体が連携して活動する場合に 90 万円 を限度に助成する団体連携活動助成を行っている。さらに, 道際の安全性之景観性に寄与する生垣化に対する助成事業 も活発である。

\section{おわりに}

この 3 年間の市民, 行政, 研究者やコンサルタンッなど の復旧・復興に向けての動向を時系列にまとめたものであ る。その結果, 行政サイドで策定されてきた復興関連の計 画は，被災直後は広域レベルの八ード整備中心であったが， 避難救援段階, 復旧段階から復興段階になるにつれ地域・ 地区レベルの計画に移行してきた状況がみられた。

また，計画レベルが住民の生活と密着したものになるに つれて, ソフト整備に関わる項目が増加し，より具体的な 防災計画になるにつれてガイドラインなどの整備マニュア ル類が提案されている。この過程で, ハード施策とソフト 施策の融合，行政と住民とのパートナーシップ，コミュニ ティ形成や助け合いなどの重要性が高まってきている。

今後, 阪神・淡路の被災地で培われ, 現在進行中である 参加型のまちづくりやそのための NPO の形成が望まれる。

\section{補注}

(*1):震災の翌年 1998 年 10 月 5 日に, 阪神グリーンネッ トの主催で開催された。緑や花の分野から復興を支援する 団体が一堂に会し，情報交換や連携強化，さらには緑から の復興まちづくりを唱えることが目的であった。 (*2):「人と自然が共生するまちづくり」をテーマとして 1998 年 8 月 22 ・23 日に開催された。神戸市シルバーカレッ ジ”での講演, 分科会や見学会に延べ約 1800 人が参加し
た。従来の, 生き物とのふれあいや環境保全活動に加え, 都市と農との関係が分科会のテーマに取り上げられた。

\section{文献リスト}

1)（社）日本造園学会阪神大震災調查特別委員会（1995）：阪神 大震災緊急調査報告書

2 ）（社）日本造園学会阪神大震災調查特別委員会（1995）：公園 緑地に関する阪神大震災緊急調查報告書

3 ）住宅・都市整備公时関西支社,（社）日本造園学会（1995）: 阪神大震災に於ける公園緑地等の災害状況調查報告書

4 ) 阪神・淡路大震災兵庫県災害対策本部（1995）：阪神・淡路 大震災一兵庫県の一カ月の記録

5 ）ひょうご創生まちづくり研究センター（1996）：阪神・淡路 大震災の仮設住宅に関する調査研究報告書

6 ）（社）日本造園学会関東支部公共造園部会（1996）：公園・緑 地の防災面からの検討と検証 一阪神 - 淡路大震災からの検 証-

7 ）住宅・都市整備公団,（社）日本造園学会（1996）：災害に強 い公園緑地等のあり方に関する基礎調查報告書

8 ) 朝日新聞社（1996）：「緑は震災に強かった一非常時の緑」: 植物の世界 120

9 )（財）兵庫地域政策研究機構（1996）: 平成 8 年度調查研究報 告「阪神・淡路大震災後の公園緑地の復旧・復興と住民参加 活動状況に関する調查研究」

10）兵庫県都市住宅部（1997）：㝿るまち・住まい

11）兵庫県，(財） 21 世紀ひょうご創造協会（1997）：街の復興力 ルテ

12）（財）都市緑化技術開発機構，公園緑地にお打引防災技術共 同研究会 (1998）：防災公園施設実態調查報告書

13）（財）兵庫地域政策研究機構（1995）：阪神 - 淡路大震災復興 政策提言

14）(株ビオシティ（1995）：自然と呼吸する都市をつくる：ビオ シティ№.4

15）(社）日本都市計画学会（1995）: 兵庫県広域緑のマスタープ ラン策定調査報告書

16）兵庫県（1995）：阪神・淡路大震災復興計画一基本構想

17）兵庫県（1995）：阪神・淡路大震災復興計画

18）兵庫県（1995）：阪神・淡路大震災都市復興計画

19）神戸市（1995）：神戸市復興計画ガイドライン

20）神戸市 (1995)：神戸市復興計画

21）兵庫県都市住宅部計画課（1996）：兵庫県防災都市計画マス タープラン（全県版）

22）兵庫県都市住宅部計画課（1997）：兵庫県防災都市計画マス タープラン（播磨地域版）

23）兵庫県都市住宅部計画課（1997）：兵庫県防災都市計画マス タープラン（但馬地域版）

24）兵庫県都市住宅部計画課（1997）：兵庫県防災都市計画マス タープラン（丹波地域版）

25）（社）ゴルファーの緑化推進協力会（1997）：防災植樹のすすめ

26）兵庫県（1997）：兵庫県防災まちづくりガイドライン

27）（財）都市緑化技術開発機構・公園緑地における防災技術共 同研究会 (1998）：公園緑地に求ける防災技術共同研究会研 究成果報告書

28）神戸市（1998）: 安全で安心な住まいとまちづくりのガイド ブック 